\title{
Desulfovibrio africanus subsp. uniflagellum subsp. nov., a sulfate-reducing bacterium from a uranium-contaminated subsurface aquifer
}

Correspondence

Lee R. Krumholz

krumholz@ou.edu

\author{
I. Nydia Castañeda-Carrión, Cody S. Sheik and Lee R. Krumholz
}

Department of Botany and Microbiology, University of Oklahoma, Norman, OK 73019, USA
Sulfate-reducing bacteria (SRB) are primarily isolated from environmental sources, such as soil, water and sediments (Postgate \& Campbell, 1966). A number of SRB have been isolated from a variety of subsurface habitats where sulfate reduction has been shown to be important. Examples include granitic aquifers (Motamedi \& Pedersen, 1998), deep sandstones (Krumholz et al., 1999; Sass \& Cypionka, 2004), a petroleum-contaminated aquifer (Allen et al., 2008) and oil reservoirs (Davidova et al., 2006). Species of the genus Desulfovibrio are members of the class Deltaproteobacteria, with more than 47 proposed species. Species of the genus Desulfovibrio isolated from freshwater and marine settings include Desulfovibrio africanus, which has typical lophotrichous flagella and has been reported to oxidize malate but not to ferment pyruvate (Campbell et al., 1966). Based on phylogenetic analysis, Desulfovibrio burkinensis and Desulfovibrio sulfodismutans are the closest relatives of D. africanus (Thabet et al., 2007). In this study, we report the isolation and characterization of strain SR-1 ${ }^{\mathrm{T}}$

Abbreviations: ITS, internal transcribed spacer; SRB, sulfate-reducing bacteria.

The GenBank/EMBL/DDBJ accession number for the 16S rRNA and dsrAB gene sequences of strain SR-1 ${ }^{\top}$ are EU659693 and EU716165, respectively.

Differential PFGE fingerprint patterns between strain $\mathrm{SR}-1^{\top}$ and $D$. africanus are available with the online version of this paper. and compare it to the closely related species $D$. africanus. Phenotypic and genotypic differences include morphology, phylogenetic analysis ( $d s r A B$ gene), DNA $\mathrm{G}+\mathrm{C}$ mol\%, DNA-DNA hybridization, genomic fingerprints using PFGE, 16S rRNA gene sequence, BOX-PCR and the presence of a small plasmid. Based on these differences, we suggest that this strain represents a novel subspecies of D. africanus.

Strain SR $-1^{\mathrm{T}}$ was isolated from a uranium-contaminated, shallow, subsurface aquifer in Shiprock-New Mexico, where the sediment contained at least $4.27 \times 10^{4} \mathrm{SRB} \mathrm{g}^{-1}$ (Castañeda Carrión, 2001). The geochemistry of the aquifer has been previously described (Chang et al., 2001, Elias et al., 2003, Schryver et al., 2006) and the aquifer has been shown to have abundant sulfate (up to $140 \mathrm{mM}$ ) and highly variable salinity, with sodium concentrations reaching as high as $411 \mathrm{mM}$ (Nevin et al., 2003) in some wells. Sulfate reduction has been shown to be an important respiratory processes in this sulfate-rich aquifer (Elias et al., 2003). The isolation of strain $\mathrm{SR}-1^{\mathrm{T}}$ was carried out at $30{ }^{\circ} \mathrm{C}$ by liquid enrichment of a $10^{-6}$ dilution of subsurface sediments in basal mineral medium containing minerals, trace metal solution, vitamins, $0.05 \%$ yeast extract, $10 \mathrm{mM}$ $\mathrm{Na}_{2} \mathrm{SO}_{4}, 25 \mathrm{mM}$ sodium lactate, $0.5 \mathrm{mM} \mathrm{Fe}\left(\mathrm{NH}_{4}\right)_{2}\left(\mathrm{SO}_{4}\right)_{2}$ and $20 \mathrm{mM}$ TES, pH 7.2, prepared under $80 \% \mathrm{~N}_{2} / 20 \%$ $\mathrm{CO}_{2}$ (Widdel \& Bak, 1992). Sterile $\mathrm{PdCl}_{2}$ and $\mathrm{NaHCO}_{3}$ 
were added to final concentrations of $0.005 \%$ and $0.07 \%$, respectively (Castañeda Carrión, 2001). The headspace contained $10 \mathrm{ml} \mathrm{H}_{2}$ gas. After three transfers, the enrichment culture was serially diluted in the same medium up to $10^{-8}$, and then anaerobically plated onto solid basal medium containing $1.5 \%$ agar. The inoculum was added to a mineral medium supplemented with $0.8 \%$ agar, overlaid onto the solid agar and incubated under $4 \%$ $\mathrm{H}_{2} / \mathrm{N}_{2}$ atmosphere in an anaerobic glovebag. After 1 week of incubation, black colonies appeared on plates that had been inoculated from the $10^{-5}$ dilution. Colonies were picked and streaked onto the solid medium described above. After a further 2 weeks of incubation, black colonies were transferred to liquid mineral medium. Pure cultures were maintained on basal liquid medium lacking $\mathrm{Fe}\left(\mathrm{NH}_{4}\right)_{2}\left(\mathrm{SO}_{4}\right)_{2}$ and reduced with $1 \mathrm{mM} \mathrm{Na} \mathrm{Na}_{2} \mathrm{~S} .9 \mathrm{H}_{2} \mathrm{O}$ instead of $\mathrm{PdCl}_{2}$ and $\mathrm{H}_{2}$ (for ease of manipulation) and all subsequent incubations were at $37^{\circ} \mathrm{C}$. Desulfoviridin was tested as described by Postgate (1984). Motility was observed by phase-contrast light microscopy, and the morphological properties were analysed by transmission electron microscopy according to standard protocols for the negative stain with uranyl acetate (Bozzola \& Russell, 1999).

The range of electron donors and electron acceptors was determined in basal medium containing $0.05 \%$ yeast extract and $1 \mathrm{mM} \mathrm{Na} 2 \mathrm{~S} .9 \mathrm{H}_{2} \mathrm{O}$ [lacking $\mathrm{Fe}\left(\mathrm{NH}_{4}\right)_{2}\left(\mathrm{SO}_{4}\right)_{2}$ ]. Electron donors were tested in medium supplemented with sterile stock solutions $(2-20 \mathrm{mM})$ of donor and with $10 \mathrm{mM}$ sulfate as the terminal electron acceptor. Hydrogen gas, when tested, was added into the gas phase of tubes. The use of electron acceptors was determined with $10 \mathrm{mM}$ lactate as the electron donor. Controls lacked donor for donor tests or acceptor for acceptor tests. After inoculation $(1 \%, v / v)$, growth rates were determined by monitoring an increase in $\mathrm{OD}_{600}$, and were regarded as positive if this exceeded 0.1 within 14 days. Fermentative growth on pyruvate was tested in sulfate-free basal medium, and acetate accumulation in the culture media was determined by gas chromatography (Mouttaki et al., 2007). Growth at a range of temperatures, $\mathrm{pH}$ and $\mathrm{NaCl}$ concentrations was determined in a modified lactate/sulfate medium (Castañeda Carrión, 2001; Rapp \& Wall, 1987). The pH range tested was from 3 to 8.5 . The buffer systems were $25 \mathrm{mM}$ sodium citrate (pH 3-6.2), $25 \mathrm{mM}$ MOPS (pH 6.5-7), $25 \mathrm{mM}$ HEPES (pH 7-8) and $25 \mathrm{mM}$ sodium carbonate ( $\mathrm{pH} 8.5)$. The $\mathrm{NaCl}$ concentrations tested were from 0.5 to $8 \%$. Growth temperature was tested at 15,20 , 25, 30, 37, 40 and $45^{\circ} \mathrm{C}$. For analysis of small-subunit rRNA sequence, internal transcribed spacer (ITS) and DSR sequences, the cultures were grown in lactate/sulfate medium and genomic DNA was isolated from $10 \mathrm{ml}$ cultures using the Easy-DNA kit (Invitrogen). DNA templates were amplified in a total reaction of $50 \mu \mathrm{l}$ containing $500 \mathrm{ng}$ of chromosomal DNA, $400 \mu \mathrm{M}$ dNTPs, $400 \mathrm{nM}$ primers, $2.5 \mathrm{mM} \mathrm{MgCl} 2$ and $2.5 \mathrm{U}$ of Platinum Taq DNA polymerase (Invitrogen). Thermal cycling conditions were adjusted according to the $\mathrm{T}_{\mathrm{m}}$ of primers and the length of the fragment to be amplified. PCR products were cloned into the TOPO-TA cloning vector according to the manufacturer's instructions (Invitrogen). For each analysis, twenty clones were picked randomly, screened by restriction digestion, and two clones were sequenced at the Oklahoma Medical Research Foundation (Oklahoma City, OK, USA). DNA sequences were subjected to a BLAST search against the GenBank database using the BLASTN algorithm. The 16S rRNA gene was amplified by using primers 8F and 1496R (Kane et al., 1993). The 16S-23S rRNA ITS was amplified with the custom-designed primer F-16S (5'-TGTAGGAGTGAAATCCGTAG-3') and the consensus primer R-23S (GarcíaMartínez et al., 1999). Complete 16S rRNA gene sequences from other species of the genus Desulfovibrio were aligned via CLUSTAL_X (Thompson et al., 1997), and distance trees were constructed with the PAUP $4.0^{\star}$ software package using the neighbour-joining algorithm and Jukes-Cantor correction. The ITS structure was analysed with IWoCS software (D'Auria et al., 2006) and tRNA genes were detected with the program tRNAscan-SE v.1.21 (Lowe \& Eddy, 1997). The $d s r A B$ gene (1983 bases) was amplified using the primer pair DSR1F and DSR4R (Wagner et al., 2005). Sequencing was completed with primers DSR1F-2 (5'-TTCCGACTTCTCGGTCATCG-3') and DSR4R-2 (5' TCCAGGATCTCGTGGTACAG-3). DsrAB amino acid sequences deduced from Desulfovibrio $d s r A B$ gene sequences greater than 1941 nucleotides were considered for comparative analysis. The 327 amino acid positions of the $\alpha$-subunit and the 216 amino acid positions of the $\beta$ subunit were used for phylogeny inference, and a distance matrix was generated using PHYLIP and the Jones-TaylorThorton model (Wagner et al., 2005). A phylogenetic tree based on the FITCH distance method was generated using ARB software (Ludwig et al., 2004).

The spectroscopic DNA-DNA hybridization between strain SR $-1^{\mathrm{T}}$ and D. africanus DSM $2603^{\mathrm{T}}$, and the DNA $\mathrm{G}+\mathrm{C}$ content of strain $\mathrm{SR}-1^{\mathrm{T}}$ were determined by the Deutsche Sammlung von Mikroorganismen und Zellkulturen. PFGE from $3 \mathrm{ml}$ exponential phase cultures was performed according to standard protocols on a CHEF-DF III system (Bio-Rad Laboratories). Briefly, the agarose embedded chromosomal DNA was digested with $20 \mathrm{U}$ of PmeI in a $200 \mu \mathrm{l}$ restriction mixture at $37^{\circ} \mathrm{C}$ for $16 \mathrm{~h}$. Running conditions were $14{ }^{\circ} \mathrm{C}, 6.0 \mathrm{~V} \mathrm{~cm}^{-1}$ for $24 \mathrm{~h}$, and a switching time linearly ramped from $60-120 \mathrm{~s}$. The $16 \mathrm{~S}$ rRNA gene fingerprints were detected by Southern blot hybridization. Genomic DNA from each strain was digested with HindIII, PstI, SphI, BmgBI and XmaI. Approximately $5 \mu \mathrm{g}$ of digested genomic DNA was separated by agarose gel electrophoresis on $0.8 \%$ agarose gels in $1 \times$ TAE buffer $(\mathrm{pH}$ 7.9) at $90 \mathrm{~V}$ for $4 \mathrm{~h}$. Gels were blotted by downward capillary transfer on positively charged nylon membranes. The $227 \mathrm{bp}$ labelled probe was amplified with a PCR DIG Probe synthesis kit (Roche) by using the custom designed primers F-16S-Hyb (5'- 
GGTGTAGGAGTGAAATCCGTAG-3) and R-16S-Hyb (5'-AGTTTCAGCCTTGCGACCGTAC-3'). The reproducibility of the 16S rRNA fingerprints was assessed similarly using new genomic DNA samples. Repetitive PCR genomic fingerprints were obtained with the BOX A1R primer (Versalovic et al., 1994). The $50 \mu \mathrm{l}$ reaction mixtures contained $4 \mathrm{mM} \mathrm{MgCl}_{2}, 200 \mu \mathrm{M}$ dNTPs, $1 \mu \mathrm{M}$ primer, $2.5 \mathrm{U}$ of Platinum Taq DNA polymerase, and $400 \mathrm{ng}$ of genomic DNA. Thermal cycling conditions were: (i) $95{ }^{\circ} \mathrm{C}$ for $5 \mathrm{~min}$; (ii) 30 cycles of $94{ }^{\circ} \mathrm{C}$ for $1 \mathrm{~min}, 50{ }^{\circ} \mathrm{C}$ for $1 \mathrm{~min}, 72{ }^{\circ} \mathrm{C}$ for $8 \mathrm{~min}$; followed by (iii) a final extension of $8 \mathrm{~min}$ at $72{ }^{\circ} \mathrm{C}$. The reproducibility and stability of BOX-PCR fingerprint patterns were verified in two independent reactions. Cultures from exponential and stationary phase were assayed for the presence of plasmids using the Qiagen plasmid mini prep protocol, except that the bacterial lysate was directly precipitated with 2propanol and $70 \%$ ethanol.

Here, we report the isolation and characterization of an abundant sulfate-reducing bacterium from uranium(VI)and sulfate-containing sediments (Elias et al., 2003). Strain SR $-1^{T}$ was isolated as a black colony that grew well with $\mathrm{H}_{2}$, lactate and sulfate in the medium used for enrichment and isolation. Substrates tested which supported growth when sulfate $(10 \mathrm{mM})$ was the electron acceptor included lactate $(10 \mathrm{mM})$, formate $(20 \mathrm{mM})$, pyruvate $(10 \mathrm{mM})$, ethanol $(10 \mathrm{mM})$ and $\mathrm{H}_{2}(10 \mathrm{ml})$. Growth with $\mathrm{H}_{2}$ was weak. Pyruvate $(10 \mathrm{mM})$ supported fermentative growth, although at low levels. Substrates which did not support growth in the presence of sulfate included acetate $(10 \mathrm{mM})$, butyrate $(10 \mathrm{mM})$, malate $(15 \mathrm{mM})$ propionate $(10 \mathrm{mM})$, methanol $(10 \mathrm{mM})$, choline $(10 \mathrm{mM})$, glucose $(2 \mathrm{mM})$ and fructose $(2 \mathrm{mM})$. Both thiosulfate and sulfite $(10 \mathrm{mM}$ each) were used as electron acceptors and reduction of elemental sulfur occurred. Growth was not detected when nitrate $(10 \mathrm{mM})$ or polysulfide $(6 \mathrm{mM})$ was used as the electron acceptor. The differential phenotypic and genotypic characteristics are shown in Table 1.

Table 1. Differential characteristics between strain $S R-1^{\top}$ and closely related species of the genus Desulfovibrio

Strains: 1 , Strain SR-1 ${ }^{\mathrm{T}} ; 2$, Desulfovibrio africanus DSM $2603^{\mathrm{T}}$ [data from this study, Campbell et al. (1966) and Skyring \& Jones (1972)]. Optimum values are shown in parentheses.

\begin{tabular}{|lcc|}
\hline Characteristic & $\mathbf{1}$ & $\mathbf{2}$ \\
\hline Cell shape & Vibrio & Sigmoid \\
Flagellation & Single polar & Lophotrichous \\
Cell size $(\mu \mathrm{m})$ & $0.5-3.5$ & $0.5 \times 5.0-10$ \\
pH range & $6.25-7.65(7)$ & $6.6-7.65(7)$ \\
Temperature range $\left({ }^{\circ} \mathrm{C}\right)$ & $20-40(37)$ & $20-40(37)$ \\
NaCl maximum $(\%)$ & 4.25 & 4 \\
DNA G + C content $(\mathrm{mol} \%)$ & 62.4 & 63.1 \\
Plasmid $(8568$ bp) & Yes & No \\
\hline
\end{tabular}

Electron microscopy analysis of negatively stained cells showed a single polar flagellum on strain SR-1 ${ }^{\mathrm{T}}$ and lophotrichous flagella on D. africanus (Fig. 1). Lophotrichous polar flagella have been described as a morphological characteristic of $D$. africanus, which was independently isolated from two different sites in Africa; both strains were identical in morphology, physiology and DNA base composition regardless of isolation source (Campbell et al., 1966). Considering that the number of flagella is a relevant morphological characteristic in species of the genus Desulfovibrio, strain $\mathrm{SR}-1^{\mathrm{T}}$ and $D$. africanus may be considered as different strains.

The growth of strain $\mathrm{SR}-1^{\mathrm{T}}$ in sulfate-free pyruvate medium coupled with acetate production $(6 \mathrm{mM})$ confirmed the fermentative metabolism of pyruvate. Growth with pyruvate as a carbon source is considered taxonomically significant for species affiliation to the genus Desulfovibrio (Postgate \& Campbell, 1966). No difference in pyruvate fermentation has been observed between Desulfovibrio subspecies (Loubinoux et al., 2002; Walker et al., 2006). Additionally, it has been reported that pyruvate does not support growth of $D$. africanus in the absence of sulfate (Campbell et al., 1966). However, our

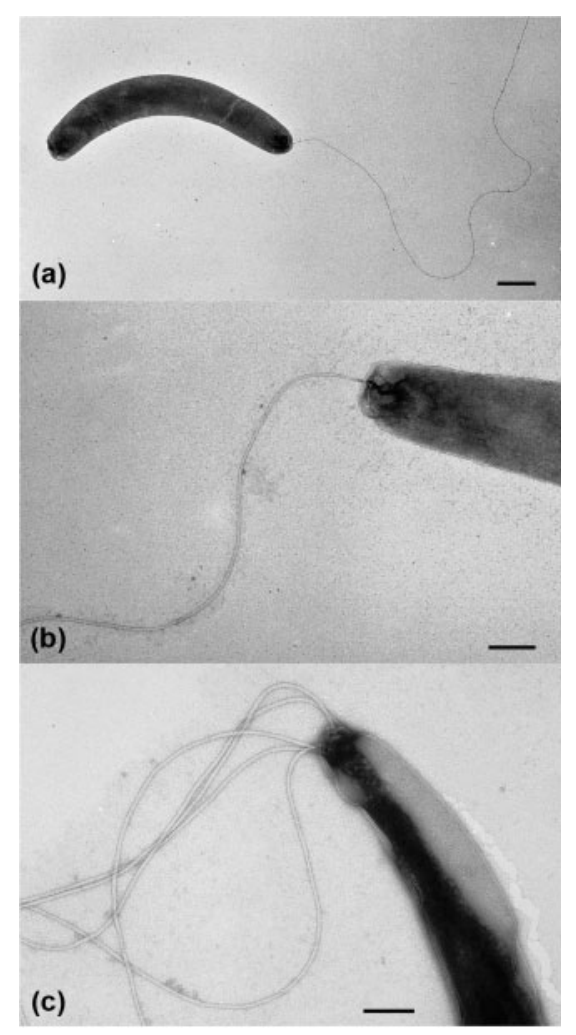

Fig. 1. Electron micrographs (negative stain with uranyl acetate) of strain $\mathrm{SR}-1^{\top}$, showing the vibrioid shape and a single polar flagellum $(a, b)$, and Desulfovibrio africanus DSM $2603^{\top}$, showing the lophotrichous flagella (c). Bars: $0.5 \mu \mathrm{m}$ (a), $0.2 \mu \mathrm{m}$ (b, c). 
experiments showed that low levels of growth occurred for both the type strain and strain SR-1 $1^{\mathrm{T}}$ on pyruvate.

For phylogenetic comparison, we sequenced 1880 nucleotides from the ribosomal operon of strain SR-1 ${ }^{\mathrm{T}}$, which includes the full-length 16S rRNA gene (1542 nucleotides), ITS region (300 nucleotides), and the $5^{\prime} 23 \mathrm{~S}$ rRNA gene. Comparative analysis of $16 \mathrm{~S}$ rRNA gene sequences revealed that strain SR-1 $1^{\mathrm{T}}$ is closely related to $D$. africanus, with $99.9 \%$ sequence similarity, which is above the $97 \%$ threshold value generally used to delineate prokaryotic species (Wayne et al., 1987). However, the discriminatory power of 16S rRNA sequences is limited when closely related species, and even different species within the same genus, are compared (Stackebrandt \& Goebel, 1994). In the genus Desulfovibrio, D. alaskensis and D. vietnamensis (Feio et al., 2004), and D. magneticus and D. burkinensis (Sakaguchi et al., 2002), are species with high 16S rRNA sequence similarities $(>98.7 \%)$. The DNA sequences of the 16S-23S ITS regions of strain SR $-1^{\mathrm{T}}$ and $D$. africanus were 300 and 299 bases in length, respectively, with each containing two tRNA genes (tRNA ${ }^{\text {Ile }}$, tRNA $^{\text {Ala }}$ ). Other characterized species of the genus Desulfovibrio have similar 16S-23S ITS regions containing either tRNA ${ }^{\text {Ile }}$ or tRNA $^{\text {Ile }}$ and tRNA ${ }^{\text {Ala }}$ genes (Loubinoux et al., 2002). Whole-genome sequences of species of the genus Desulfovibrio (NC_002937 and NC_008751) have also revealed that the ITS regions are conserved in size and type of tRNA genes. Comparative analysis revealed that the ITS sequence of strain SR $-1^{\mathrm{T}}$ is $99 \%$ similar to that of $D$. africanus. Thus, the ITS region is not a useful marker to differentiate these closely related Desulfovibrio strains. Based on phylogenetic analysis of DsrAB amino acid sequences (Fig. 2), strain SR-1 $1^{\mathrm{T}}$ is related to D. africanus with a $94.66 \%$ sequence similarity. A similar phylogenetic affiliation has been reported for Desulfovibrio aerotolerans and D. burkinensis, with a $96.8 \%$ DsrAB amino acid sequence similarity (Mogensen et al., 2005). There is no threshold value of $d s r A B$ gene sequence divergence for species affiliation, but complete genome sequences of closely related strains of Desulfovibrio vulgaris have confirmed that they have identical $d s r A B$ sequences. Our results indicate that the $d s r A B$ gene may offer an advantage over the 16S rRNA gene and 16S-23S ITS region in defining sequence divergence between closely related Desulfovibrio strains.

Considering that comparisons between some species of the genus Desulfovibrio with high 16S rRNA gene sequence similarities (Feio et al., 2004; Sakaguchi et al., 2002) did not meet the $70 \%$ DNA-DNA hybridization criterion for inclusion in the same species (Wayne et al., 1987), the DNA-DNA hybridization between strain SR-1 ${ }^{\mathrm{T}}$ and $D$. africanus was assayed and shown to be $72 \%$. It is important to note that a $90 \%$ DNA-DNA hybridization value was reported when closely related Desulfovibrio vulgaris strains were inspected (Brandis \& Thauer, 1981). In the genus Pseudomonas, phenotypic differences have been considered to reclassify Pseudomonas aureofaciens DSM $6698^{\mathrm{T}}$ as a subspecies of Pseudomonas chlororaphis, despite a 73-81\% DNA-DNA similarity with other subspecies and a $16 \mathrm{~S}$ rRNA gene sequence similarity of greater than $99.4 \%$ (Peix et al., 2007). The DNA G+C content of $62.4 \mathrm{~mol} \%$ obtained for strain SR-1 ${ }^{\mathrm{T}}$ differs from the value of $63.1 \mathrm{~mol} \%$ reported for the type strain D. africanus (Skyring \& Jones, 1972). Since determination of the genomic $\mathrm{G}+\mathrm{C}$ content lacks resolution for determining relationships between strains (Rossello-Mora \& Amann, 2001), the DNA mol\% G + C determination for strain SR$1^{\mathrm{T}}$ constitutes complementary information for its description. PFGE revealed the presence of three PmeI-fragments in strain SR- $1^{\mathrm{T}}$ and six PmeI-fragments in D. africanus (Supplementary Fig. S1, available in IJSEM Online). The separation of macrorestriction fragments by PFGE generates DNA banding patterns that can be used to evaluate interspecies and intraspecies genetic variation. Here we have considered that bacterial isolates differing by one to three bands are closely related strains (Tenover et al., 1995). Considering this difference, strain SR- $1^{\mathrm{T}}$ and $D$. africanus may be considered closely related strains. $16 \mathrm{~S}$ rRNA gene fingerprint patterns (Fig. 3) indicate that strain SR $-1^{\mathrm{T}}$ can be distinguished from $D$. africanus based on variation of restriction sites within $(S p h \mathrm{I}, X m a \mathrm{I})$ and around (BmgBI, HindIII, PstI) the 16S rRNA gene. The number of $16 \mathrm{~S}$ rRNA gene hybridization bands depends on the restriction enzyme and the location of the restriction sites in the genome (Pukall, 2006). Despite the same number of hybridization bands, the different $16 \mathrm{~S}$ ribo-

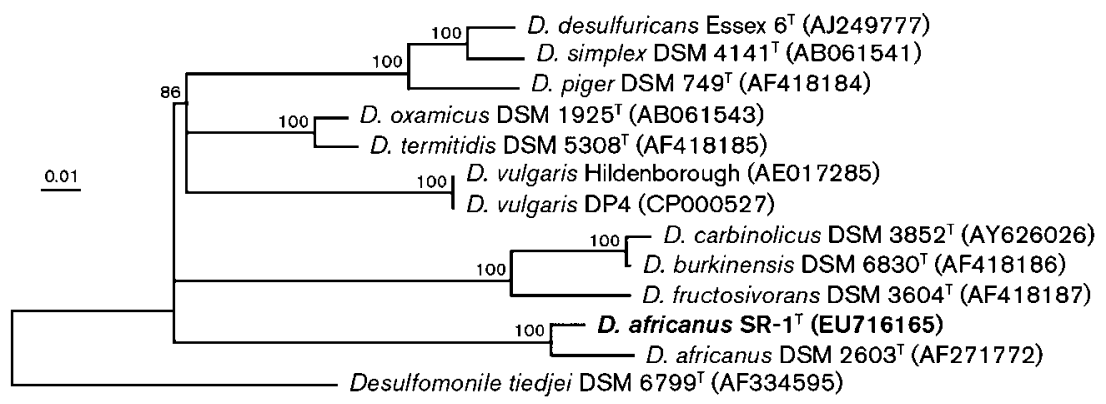

http://ijs.sgmjournals.org
Fig. 2. Phylogenetic tree of Desulfovibrio DsrAB amino acid sequences showing the affiliation of strain $\mathrm{SR}-1^{\top}$. Sequences were retrieved from the GenBank database; accession numbers are given in parentheses. Bootstrap values (\%) are based on 1000 replicates. The sequence of Desulfomonile tiedjei was included as the outgroup. Bar, 0.01 substitutions per site. 

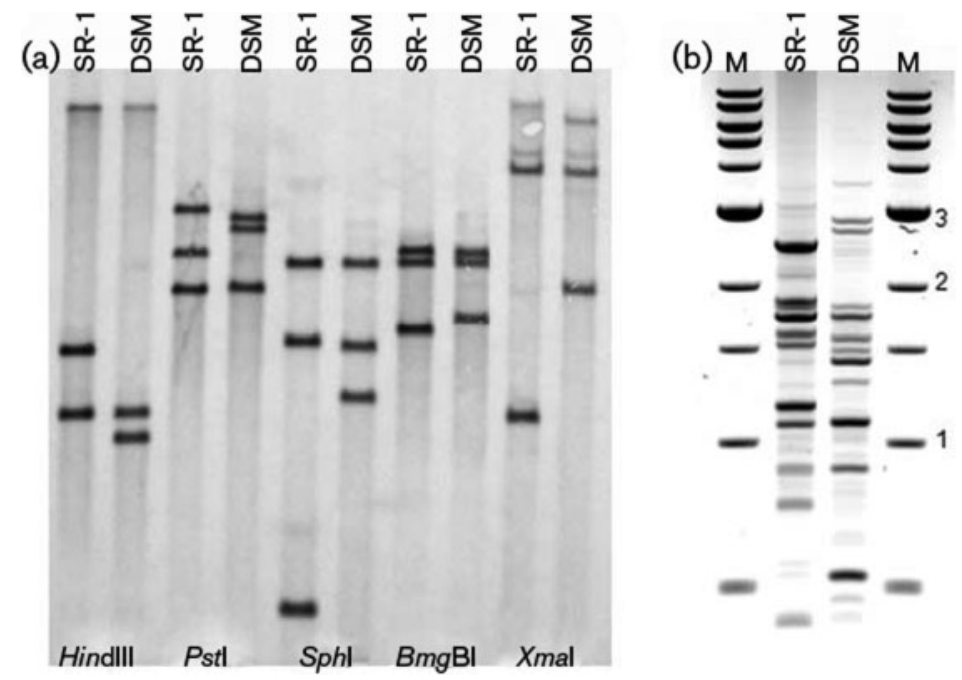

Fig. 3. Differential $16 \mathrm{~S}$ rRNA gene sequence (a) and BOX-PCR (b) fingerprint patterns of strain $\mathrm{SR}-1^{\top}$ as compared with $D$. africanus. (a) Southern blot hybridization of genomic DNA digested with Hindlll, Pstl, Sphl, BmgBI and Xmal. (b) Agarose gel of $10 \mu$ aliquots of PCR products amplified with the BOX A1R primer. SR-1, Strain SR-1 ${ }^{\top}$; DSM, D. africanus DSM $2603^{\top} ; \mathrm{M}$, DNA ladder.

somal fingerprint patterns generated suggested that the genomes of strain SR-1 ${ }^{\mathrm{T}}$ and $D$. africanus have a different organization. Identical BOX-PCR fingerprint patterns were observed on replicate gels, but significant differences in the fingerprint patterns between strains were observed (Fig. 3). Rep-PCR techniques, which include BOX-PCR, have been shown to be valuable tools for classifying and typing a variety of Gram-negative bacteria (Versalovic et al., 1994). ERIC- and REP-PCR fingerprints have been used in an attempt to differentiate soil from intestinal strains of Desulfovibrio desulfuricans (Dzierzewicz et al., 2003). The results presented here suggest that strain $\mathrm{SR}-1^{\mathrm{T}}$ has a different genomic organization from $D$. africanus.

A small plasmid was purified only from either exponential or stationary phase cultures of strain SR-1 $1^{\mathrm{T}}$. The absence of plasmids in D. africanus has been previously reported (Postgate, 1984) and was confirmed in the present study.

The ad hoc committee on reconciliation of approaches to bacterial systematics has proposed that subspecies designations can be used for genetically close organisms that can be differentiated by some phenotypic characteristics (Wayne et al., 1987). Salient phenotypic characteristics of strain SR-1 ${ }^{\mathrm{T}}$ (single polar flagellum), and differential DNA fingerprints (PmeI-PFGE, 16S rRNA gene sequence and BOX-PCR), indicate that strain SR-1 ${ }^{\mathrm{T}}$ constitutes a novel subspecies of $D$. africanus, for which the name Desulfovibrio africanus subsp. uniflagellum subsp. nov. is proposed.

\section{Description of Desulfovibrio africanus subsp. africanus Campbell et al. 1966, subsp. nov.}

Desulfovibrio africanus subsp. africanus (a.fri.ca'nus. L. adj. africanus pertaining to Africa).

Motile, vibrio-shaped cells with multiple polar flagella (lophotrichous) and $0.5 \times 5-10 \mu \mathrm{m}$ in size. Grow at $\mathrm{pH} 6.6$ to 7.65 and at $20-40{ }^{\circ} \mathrm{C}$. No growth is observed at 15 or $45^{\circ} \mathrm{C}$. Does not require $\mathrm{NaCl}$ for growth, but can grow with up to $4.0 \% \mathrm{NaCl}$. Lactate, pyruvate, ethanol and formate are oxidized with sulfate reduction. Substrates that do not support growth with sulfate include acetate, propionate, malate, butyrate, choline, glucose and fructose. Sulfite and thiosulfate are used as electron acceptors and elemental sulfur is weakly reduced $(10 \mathrm{mM}$ each). Nitrate is not used as an electron acceptor. The DNA G+C content of the type strain is $63.1 \mathrm{~mol} \%$. DNA-DNA hybridization between the type strain and the type strain of $D$. africanus subsp. uniflagellum is $72 \%$.

The type strain is ATCC $19996^{\mathrm{T}}\left(=\mathrm{DSM} 2603^{\mathrm{T}}=\mathrm{NCIB}\right.$ (now NCIMB) $8401^{\mathrm{T}}=$ VKM B-1757 ${ }^{\mathrm{T}}$ ).

\section{Description of Desulfovibrio africanus subsp. uniflagellum subsp. nov.}

Desulfovibrio africanus subsp. uniflagellum [uni.fla.gel'lum. L. adj. unus only one, one; L. n. flagellum whip; N.L. neut. $\mathrm{n}$. (nominative in apposition) uniflagellum the only one whip].

Motile, vibrio-shaped cells with a single polar flagellum and $0.5-3.5 \mu \mathrm{m}$ in size. Grow at $\mathrm{pH} 6.25$ to 7.65 , with optimum growth at $\mathrm{pH} 7.0$, and at $20-40{ }^{\circ} \mathrm{C}$, with optimum growth at $37{ }^{\circ} \mathrm{C}$. No growth is observed at 15 or $45^{\circ} \mathrm{C}$. Does not require $\mathrm{NaCl}$ for growth, but can grow with up to $4.25 \% \mathrm{NaCl}$. Lactate, formate, pyruvate, ethanol and hydrogen are oxidized with sulfate reduction. Substrates that do not support growth with sulfate include acetate, propionate, malate, butyrate, choline, glucose and fructose. Pyruvate supports fermentative growth. Nitrate is not used as an electron acceptor. Habitat: shallow subsurface aquifer. The DNA G $+\mathrm{C}$ content of the type strain is $62.4 \mathrm{~mol} \%$. DNA-DNA hybridization between the type strain and the type strain of $D$. africanus subsp. africanus is $72 \%$.

The type strain is SR-1 ${ }^{\mathrm{T}}\left(=\mathrm{JCM} 15510^{\mathrm{T}}=\mathrm{KCTC} 5649^{\mathrm{T}}\right)$, which was isolated from subsurface sediments of a 
uranium-contaminated site in Shiprock, New Mexico, USA.

\section{Acknowledgements}

This work was supported by the US Department of Energy, Environmental Remediation Science Program (ERSP) of the Office of Biological and Environmental Research of the Office of Science. Part of the work of I.N.C.-C. was supported by a Fulbright Fellowship. We would like to thank Dr F. M. M. Morel at Princeton University for providing the type strain, Dr Dwayne Elias for sharing the sediment sample and Gregory Strout at the Samuel Roberts Noble Electron Microscopy Laboratory for technical assistance.

\section{References}

Allen, T. D., Kraus, P. F., Lawson, P. A., Drake, G. R., Balkwill, D. L. \& Tanner, R. S. (2008). Desulfovibrio carbinoliphilus sp. nov., a benzyl alcohol-oxidizing, sulfate-reducing bacterium isolated from a gas condensate-contaminated aquifer. Int J Syst Evol Microbiol 58, 13131317.

Bozzola, J. J. \& Russell, L. D. (1999). Electron Microscopy: Principles and Techniques for Biologists. 2nd edn. Sudbury, MA: Jones and Bartlett.

Brandis, A. \& Thauer, R. K. (1981). Growth of Desulfovibrio species on hydrogen and sulphate as sole energy source. J Gen Microbiol 126, 249-252.

Campbell, L. L., Kasprzychi, M. A. \& Postgate, J. R. (1966). Desulfovibrio africanus sp. n., a new dissimilatory sulfate-reducing bacterium. J Bacteriol 92, 1121-1127.

Castañeda Carrión, I. N. (2001). Isolation and genetic characterization of subsurface microorganisms. MS thesis, University of Oklahoma.

Chang, Y.-J., Peacock, A. D., Long, P. E., Stephen, J. R., McKinley, J. P., Macnaughton, S. J., Hussain, A. K. M. A., Saxton, A. M. \& White, D. C. (2001). Diversity and characterization of sulfate-reducing bacteria in groundwater at a uranium mill tailings site. Appl Environ Microbiol 67, 3149-3160.

D’Auria, G., Pushker, R. \& Rodriguez-Valera, F. (2006). IWoCS: Analyzing ribosomal intergenic transcribed spacers configuration and taxonomic relationships. Bioinformatics 22, 527-531.

Davidova, I. A., Duncan, K. E., Choi, O. K. \& Suflita, J. M. (2006). Desulfoglaeba alkanexedens gen. nov., sp. nov., an n-alkane-degrading, sulfate-reducing bacterium. Int J Syst Evol Microbiol 56, 2737-2742.

Dzierzewicz, Z., Szczerba, J., Weglarz, L., Swiatkowska, L., Jasinska, D. \& Wilczok, T. (2003). Intraspecies variability of Desulfovibrio desulfuricans strains determined by the genetic profiles. FEMS Microbiol Lett 219, 6974.

Elias, D. A., Krumholz, L. R., Wong, D., Long, P. E. \& Suflita, J. M. (2003). Characterization of microbial activities and $U$ reduction in a shallow aquifer contaminated by uranium mill tailings. Microb Ecol 46, 83-91.

Feio, M. J., Zinkevich, V., Beech, I. B., Llobet-Brossa, E., Eaton, P., Schmitt, J. \& Guezennec, J. (2004). Desulfovibrio alaskensis sp. nov., a sulphate-reducing bacterium from a soured oil reservoir. Int J Syst Evol Microbiol 54, 1747-1752.

Garcia-Martínez, J., Acinas, S. G., Antón, A. I. \& Rodríguez-Valera, F. (1999). Use of the 16s-23s ribosomal genes spacer region in studies of prokaryotic diversity. J Microbiol Methods 36, 55-64.

Kane, M. D., Poulsen, L. K. \& Stahl, D. A. (1993). Monitoring the enrichment and isolation of sulfate-reducing bacteria by using oligonucleotide hybridization probes designed from environmentally derived 16s rRNA sequences. Appl Environ Microbiol 59, 682-686.

Krumholz, L. R., Harris, S. H., Tay, S. T. \& Suflita, J. M. (1999). Characterization of two subsurface $\mathrm{H}_{2}$-utilizing bacteria, Desulfomicrobium hypogeium sp. nov. and Acetobacterium psammolithicum sp. nov., and their ecological roles. Appl Environ Microbiol 65, 2300-2306.

Loubinoux, J., Valente, F. M. A., Pereira, I. A. C., Costa, A., Grimont, P. A. D. \& Le Faou, A. E. (2002). Reclassification of the only species of the genus Desulfomonas, Desulfomonas pigra, as Desulfovibrio piger comb. nov. Int J Syst Evol Microbiol 52, 1305-1308.

Lowe, T. M. \& Eddy, S. R. (1997). tRNAscan-SE: A program for improved detection of transfer RNA genes in genomic sequence. Nucleic Acids Res 25, 955-964.

Ludwig, W., Strunk, O., Westram, R., Richter, L., Meier, H., Yadhukumar, Buchner, A., Lai, T., Steppi, S. \& other authors (2004). ARB: a software environment for sequence data. Nucleic Acids Res 32, 1363-1371.

Mogensen, G. L., Kjeldsen, K. U. \& Ingvorsen, K. (2005). Desulfovibrio aerotolerans sp. nov., an oxygen tolerant sulphatereducing bacterium isolated from activated sludge. Anaerobe 11, 339349.

Motamedi, M. \& Pedersen, K. (1998). Desulfovibrio aespoeensis sp. nov., a mesophilic sulfate-reducing bacterium from deep groundwater at Äspö hard rock laboratory, Sweden. Int J Syst Bacteriol 48, 311-315.

Mouttaki, H., Nanny, M. A. \& McInerney, M. J. (2007). Cyclohexane carboxylate and benzoate formation from crotonate in Syntrophus aciditrophicus. Appl Environ Microbiol 73, 930-938.

Nevin, K. P., Finneran, K. T. \& Lovley, D. R. (2003). Microorganisms associated with uranium bioremediation in a high-salinity subsurface sediment. Appl Environ Microbiol 69, 3672-3675.

Peix, A., Valverde, A., Rivas, R., Igual, J. M., Ramírez-Bahena, M.-H., Mateos, P. F., Santa-Regina, I., Rodríguez-Barrueco, C., MartínezMolina, E. \& Velázquez, E. (2007). Reclassification of Pseudomonas aurantiaca as a synonym of Pseudomonas chlororaphis and proposal of three subspecies, $P$. chlororaphis subsp. chlororaphis subsp. nov., $P$. chlororaphis subsp. aureofaciens subsp. nov., comb. nov. and $P$. chlororaphis subsp. aurantiaca subsp. nov., comb. nov. Int J Syst Evol Microbiol 57, 1286-1290.

Postgate, J. R. (1984). The Sulphate-reducing Bacteria. 2nd edn. Cambridge: Cambridge University Press.

Postgate, J. R. \& Campbell, L. L. (1966). Classification of Desulfovibrio species, the nonsporulating sulfate-reducing bacteria. Bacteriol Rev 30, 732-738.

Pukall, R. (2006). DNA fingerprinting techniques applied to the identification, taxonomy and community analysis of prokaryotes. In Molecular Identification, Systematics, and Population Structure of Prokaryotes. pp. 51-82. Edited by E. Stackebrandt. Berlin, Heidelberg: Springer.

Rapp, B. J. \& Wall, J. D. (1987). Genetic transfer in Desulfovibrio desulfuricans. Proc Natl Acad Sci U S A 84, 9128-9130.

Rosselló-Mora, R. \& Amann, R. (2001). The species concept for prokaryotes. FEMS Microbiol Rev 25, 39-67.

Sakaguchi, T., Arakaki, A. \& Matsunaga, T. (2002). Desulfovibrio magneticus sp. nov., a novel sulfate-reducing bacterium that produces intracellular single-domain-sized magnetite particles. Int J Syst Evol Microbiol 52, 215-221.

Sass, H. \& Cypionka, H. (2004). Isolation of sulfate-reducing bacteria from the terrestrial deep subsurface and description of Desulfovibrio cavernae sp. nov. Syst Appl Microbiol 27, 541-548. 
Schryver, J. C., Brandt, C. C., Pfiffner, S. M., Palumbo, A. V., Peacock, A. D., White, D. C., McKinley, J. P. \& Long, P. E. (2006). Application of nonlinear analysis methods for identifying relationships between microbial community structure and groundwater geochemistry. Microb Ecol 51, 177-188.

Skyring, G. W. \& Jones, H. E. (1972). Guanine plus cytosine contents of the deoxyribonucleic acids of some sulfate-reducing bacteria: a reassessment. J Bacteriol 109, 1298-1300.

Stackebrandt, E. \& Goebel, B. M. (1994). Taxonomic note: a place for DNA-DNA reassociation and $16 \mathrm{~S}$ rRNA sequence analysis in the present species definition in bacteriology. Int J Syst Bacteriol 44, 846-849.

Tenover, F. C., Arbeit, R. D., Goering, R. V., Mickelsen, P. A., Murray, B. E., Persing, D. H. \& Swaminathan, B. (1995). Interpreting chromosomal DNA restriction patterns produced by pulsed-field gel electrophoresis: criteria for bacterial strain typing. J Clin Microbiol 33, 2233-2239.

Dhia Thabet, O. B., Fardeau, L.-M., Suarez-Nuñez, C., Hamdi, M., Thomas, P., Ollivier, B. \& Alazard, D. (2007). Desulfovibrio marinus sp. nov., a moderately halophilic sulfate-reducing bacterium isolated from marine sediments in Tunisia. Int J Syst Evol Microbiol 57, 2167-2170.

Thompson, J. D., Gibson, T. J., Plewniak, F., Jeanmougin, F. \& Higgins, D. G. (1997). The CLUSTAL_X windows interface: flexible strategies for multiple sequence alignment aided by quality analysis tools. Nucleic Acids Res 25, 4876-4882.

Versalovic, J., Schneider, M., de Bruijn, F. J. \& Lupski, J. R. (1994). Genomic fingerprinting of bacteria using repetitive sequencebased polymerase chain reaction. Methods Mol Cell Biol 5, 2540 .

Wagner, M., Loy, A., Klein, M., Lee, N., Ramsing, N. B., Stahl, D. A. \& Friedrich, M. W. (2005). Functional marker genes for identification of sulfate-reducing prokaryotes. Methods Enzymol 397, 469-489.

Walker, C. B., Stolyar, S. S., Pinel, N., Yen, B., He, Z., Zhou, J., Wall, J. D. \& Stahl, D. A. (2006). Recovery of temperate Desulfovibrio vulgaris bacteriophage using a novel host strain. Environ Microbiol 8, 19501959.

Wayne, L. G., Brenner, D. J., Colwell, R. R., Grimont, P. A. D., Kandler, O., Krichevsky, M. I., Moore, L. H., Moore, W. E. C., Murray, R. G. E. \& other authors (1987). International Committee on Systematic Bacteriology. Report of the ad hoc committee on reconciliation of approaches to bacterial systematics. Int J Syst Bacteriol 37, 463-464.

Widdel, F. \& Bak, F. (1992). Gram-negative mesophilic sulfatereducing bacteria. In The Prokaryotes, 2nd edn, vol IV, pp. 3352-3378. Edited by A. Balows, H. G. Trüper, M. Dworkin, W. Harder \& K. H. Schleifer. New York: Springer. 